\title{
Defining Tech: An Examination of How the 'Technology' Economy is Measured
}

\author{
C. A. Hooton \\ The George Washington University Institute of Public Policy, USA \\ E-mail: chooton@gwu.edu
}

Received 28 November 2018;

Accepted 04 December 2018

\begin{abstract}
The paper conducts a comprehensive review and critical comparison of the empirical methodologies for defining the high-technology sector (or 'tech') in social science research and analysis. It consolidates both qualitative (expert-based) approaches and quantitative (threshold-based) approaches for the broader audience of researchers. In the quantitative approaches, the paper identifies two accepted metrics and two loosely defined criteria used in distinguishing tech. The paper finds a generally consistent theoretical conceptualization for how to distinguish tech from other sectors, but inconsistency and no consensus on the implementation of that theory in applied research methods. The paper proposes two steps forward for future methodologies by identifying of a set of consensus industries present across tech definitions and by arguing for a continuum-based approach to identifying technology intensity in industries, businesses, and products/services.
\end{abstract}

Keywords: Technology sector, digital economy, online platforms, technology theory, measurement of technology.

\section{Introduction}

Some exclaim the lack of a standard definition for the high-technology sector. They perhaps overstate the need given there are several accepted methods used in empirical research. However, the sentiment is an accurate reflection of

Journal of NBICT, Vol. 1, 101-120.

doi: 10.13052/nbjict1902-097X.2018.007

This is an Open Access publication. (c) 2018 the Author(s). All rights reserved. 
the lack of research examining the theoretical foundations underlying them in other words, their accuracy.

The high-technology sector (or simply 'tech') is a term used colloquially to describe firms and industries that either produce or utilize cutting-edge technology as part of their business model. While, it is generally quite easy to identify a handful of firms that serve as prototypical examples of tech companies (e.g., Spotify, Google, etc.), a standard operational definition of the tech sector remains elusive. National data sources and agencies across the world fail to provide a formal definition and no research has critically examined the quality or consistency of the few attempts that have been made. The most recent and closest research to presenting a tech definition is likely from the US Bureau of Economic Analysis (BEA) [1]; however, this measures the US digital economy, which is a unique and not an interchangeable concept with tech.

The goal of the current paper is to critically examine the theory and methods for identifying the technology sector and to provide practical guidance on how it is measured, including strengths and weaknesses of current approaches. Crucially, the paper argues research should move beyond a dichotomous (tech vs non-tech) approach toward a more nuanced tech definition and proposes the first, to the extent of the author's knowledge, continuumbased technology intensity index. In the process, the paper develops new insights into the theoretical and conceptual aspects of what defines tech namely the distinction between tech development and tech application by firms and industries.

There are obvious benefits to more clearly defining high-tech industries for social science research purposes. A consistent methodology would prove immensely beneficial from an economic measurement standpoint (e.g. industry projections) and for a variety of sociological, planning, and geography topic areas examining firm locations, industry concentrations, demographic effects, as well as others. A comprehensive list, founded in real-world datasets, would allow for an actual tech sector taxonomy to be constructed and refined, thus improving our understanding of a very nuanced sector. For example, it seems crude to consider businesses like Airbnb, Facebook, and Dell - which are all tech companies - one and the same despite some obvious similarities. Additionally, this paper argues our current understanding of the tech sector and methods for studying it rely far too much on 'expertise' and arbitrary cut-offs rather than on objective classifications founded in robust theory that can be tested and improved over time. 
The paper begins in Section 2 with an examination of the underlying theory in definitions of the technology sector and a comparison of applied approaches. Section 3 presents its analytical exercises, conducting a critical comparison of existing definition approaches and offering a new approach for how tech should be defined in research. Section 4 discusses and Section 5 concludes.

\section{Definitional Theory and Approaches in the Literature}

\subsection{Core Characteristics}

Across the small body of work examining tech sector definitions, there is remarkable agreement on four theoretical characteristics that distinguish tech (i.e. technology firms and industries). These are: 1) High Investment in Research \& Development (R\&D); 2) High Number of Employees Educated in STEM; 3) Complexity in Production and/or Product/Service; and, 4) Novelty in Production and/or Product/Service. Researchers generally use any one or combination of these to distinguish the tech sector or one of its component industries [2-7].

Beyond the common use of these components, however, researchers vary widely in three respects. First, there is no accepted approach for determining the threshold for individual metrics (e.g. how much a company needs to invest in R\&D to be considered tech). Second, there is no consensus on how many of these four characteristics are needed to distinguish tech (e.g. if a firm must qualify in one of the characteristics, two of the characteristics, etc.). Third, there is disagreement on the dimensionality between them (e.g. if an industry that has sufficiently high numbers of science, technology, engineering, and mathematics (STEM) employees can compensate for lower levels of R\&D investment). The differences between how these characteristics are operationalized in methodologies may seem mundane, but they can lead to significant differences in definitions and measurements of an industry with a nebulous identity and major social and economic impacts. There are two differing approaches for determining the exact criteria for these components the use of expert panels and quantitative thresholds for individual metrics.

The expert panel approach is akin to reasoned intuition. A group of experts determines the exact criteria generally according to characteristics (principally the four identified here) and then decides whether individual firms or industries are indeed part of the tech sector. It is an approach that harnesses intuitive distinctions between low- and high-tech, though perhaps with a bit more systematization. The obvious weakness of this approach is that the designations are subjective and not particularly generalizable since 
different panels likely have different experts while the same panels will not have the same experts over time. Without methodological adjustment, the likely result is bias toward firms or industries that are (appear) 'prototypical' in their tech-orientation and against firms or industries that deviate from the prototype $[2-4,8]$.

The quantitative threshold approach offers a more replicable distinction between low-tech and high-tech. Researchers determine quantitative cutoffs for one or more theoretical factors to determine tech versus non-tech groups, often based on some quantile or population-reference (e.g. standard deviations). The strength of the approach is that it allows atypical firms or industries to be included as high-tech even though they are less intuitively associated with tech. The principal weakness, however, relates to how the threshold is set and has two parts. First, quantile-based thresholds, are likely themselves arbitrary. Second, population-referenced thresholds, which remove some arbitrariness, do not allow the percentage of industries classified as tech to change [4-6].

At issue is the balance between accuracy/nuance, comprehensiveness, and intuitiveness. Definitions that tend toward more stringent criteria may inadvertently exclude firms that employ proportionately large numbers of employees without a science background but which nevertheless invests heavily in R\&D or vice versa. Expert panels may develop logical lists, but miss key components of the technology sector. Thresholds may exclude nascent firms or business lines. A binary conceptualization underlies these trade-offs and has been applied at three levels - industries (i.e. industrial codes), firms, and or their product(s)/service(s). The paper addresses each of these in turn.

\subsection{Industry-Level Approaches}

Tech sector definitions utilizing the industry level are the most prevalent approach and, this paper argues, the most wedded to the realities and limitations of most relevant datasets. Among these, the most frequently cited set of industries comes from researchers at the United States Bureau of Labor Statistics [4]. The works appear, however, to be unofficial - while there are publications written based on the BLS definition by government employees, the industry list is not included in official data.

The BLS methodology utilizes a threshold approach and appears to be the most prevalent among academics examining industry-level aggregated data. Due to its prevalence, this report argues that the BLS implementation is probably the closest to a standard in the literature. 
The initial BLS definition came from Chapple et al. [9] and drew on SIC codes. Later, Hecker [4] updated the approach using newer NAICS codes while reiterating the theoretical underpinnings of Chapple et al. [9]. Specifically, the authors stipulated the industries comprising tech should have the following characteristics:

- A high proportion of STEM employees (STEM intensity);

- A high proportion of R\&D employment (R\&D employment intensity);

- Production of high-tech products, as specified on a Census Bureau list of advanced-technology products;

- Use of high-tech production methods, including intense use of high-tech capital goods and services in the production process.

Despite having four theoretical characteristics, however, the BLS researchers opted to implement their definition only through the proportion of scientists, engineers, and technicians in an industry. The researchers determined employment figures for scientists, engineers, and technicians through the Standard Occupation Classification (SOC) and then determined the number of employees for each industry using the BLS National Employment Matrix. If the percentage of scientists, engineers, and technicians employed in an industry was at least twice the national average (4.9 percent in 2005) they considered the industry part of the tech sector.

Many groups have used the BLS approach or a derivation thereof in their research [10-14], but the approach suffers from a seemingly arbitrary cut-off for the concentration of scientists, engineers, and technicians employed. It should also be noted that since the proportion of science-oriented employees within each industry and the national average proportion are both dynamic, thus requiring regular updates.

The authors at the Brookings Institute [3] offer the first explicit definition (i.e. list of industries) of tech found by the author and the first to utilize North American Industrial Classification System (NAICS) codes in that definition. The piece reviewed all NAICS and Standard Industrial Classification (SIC) codes) and 'hand-picked' those which best represented the technology sector - these were: Electronic Computers (SIC 357), Electrical Machinery (SIC 36), Instruments (SIC 38), Software and Data Processing Services (SIC 737), Computer and Electronic Product Manufacturing (NAICS 334), Software Publishers (NAICS 5112), Information and Data Processing Services (NAICS 514), and Computer Systems Design and Related Services (NAICS 5415). The work provides useful guidance and a clear starting point for researchers examining the sector; however, it suffers from the same issues of all expert-based approaches. 
More recently, further work by the Brookings researchers [5] extended the utilization of industry-level definition lists, but switched away from an expert approach to a threshold approach. The authors utilized R\&D expenditures provided by the National Science Foundation's annual Business R\&D and Innovation Survey and a metric for the concentration of STEM occupations relative to typical occupations built using a survey.

First, the authors identified occupations that were at least 1.5 standard deviations above the mean in STEM knowledge relation. Second, the authors then used the BLS National Employment Matrix to identify which NAICS industries had more STEM employees than the national average - the cutoff was at $21 \%$ of industry employment. Finally, the authors set a cutoff for R\&D expenditure at $\$ 450$ per worker to identify the tech sector. The approach added welcome nuance to the definition the sector allowing atypical industries to be included and by using more than one theoretical component in its definition. Yet, its use of a proprietary survey on STEM and imputed 4-digit R\&D figures (imputed from 3-digit codes) make the approach harder to validate.

Finally, the trade group Information Technology Industry and Association (or CompTIA) provides a set of NAICS codes as their own (self) definition of the tech industry. Based on these codes, CompTIA releases annual statistics for the sector. The association uses an expert-panel approach that emphasizes complexity of production and selects industry codes that are "... involved in making, creating, enabling, integrating, or supporting technology, whether as a product or service [2: pp. 128]." The organization currently uses about 50 NAICS codes, broadly separated into tech manufacturing and tech services categories, to define the tech industry (see Appendix). The approach benefits (and suffers) from being an 'insider' perspective.

\subsection{Firm-Level Approaches}

A unique aspect of firm-level approaches is the ability to use surveys to identify technology firms. O'Regan and Sims [6] pioneered this approach for defining tech with a postal survey of firms with questions based on four definitional elements:

- Degree of emphasis on and investment in R\&D (via R\&D expenditure compared to total sales and number of full-time employees);

- Innovation (via a rating of importance of innovation as a competitive factor, organizational direction, and being first to market);

- Creativity (via a rating of the importance of the introduction of new products, degree of staff creativity, and ability to customize products);

- Capabilities (via a rating of staff competencies and their importance). 
Their findings indicated that only a subset of firms belonging to engineering and electronics sectors exhibited high-tech characteristics. They found firms related to mechanical, distribution, and other manufacturing activities were "less high-tech" than firms related to electronics production, IT/software development, and electrical production. While this may seem an a priori observation, the study provides quantitative evidence that industry-wide, blanket designations of tech have been unable to provide.

It should be noted, however, that O'Regan and Sims's study [6] has two major shortcomings. First, the study utilizes they survey used individuals' perceptions to determine the degree of a firm's priorities on R\&D, innovation, creativity, and capability. These suffer from the usual non-respondent and response biases of qualitative approaches. Second, the study opted to use firm growth and profitability as indicators of a "high tech" firm, which this paper argues is better suited as a prediction outcome rather than a core definitional characteristic of tech.

Finally, Kile and Phillips [8] examined tech with a blended methodology. They first identified the SIC codes used to designate high-tech industries in previous research from 1996 through 2006 (Computer Equipment: 357; Software: 737; Medical Technologies: 283, 382, 384; Communications: 366, 481, 489; Electrical: 360-365, 367). The authors then supplemented these codes with relevant NAICS and GSIC codes and benchmarked the performance of various combinations based on the 10-K disclosures of approximately 3,100 tech firms selected by experts. When they compared the designations with their own expert-panel benchmark designations (based on firm 10-K filings), they again found large discrepancies between the benchmark and the industry-level designations.

\subsection{Product/Service-Level Approaches}

Finally, some have also operationalized tech definitions thorugh products/services. Steenhuis and de Bruijn [7] propose a product-level approach to defining the technology sector based on the amount of R\&D invested into the production of specific goods. Their approach better elucidated how the defining theoretical characteristics of complexity could be conceptualized and it provides a potential approach for implementing the concepts of complexity and newness through an expert-panel. However, the authors do not attempt any empirical work based on the approach. Earlier, Hansen and Serin [15] implicitly discussed a similar approach, but also do not conduct an empirical exercise. Indeed, this paper has been unable to find any empirical work based 
on the idea and speculates the lack of empirical application may relate to the difficulty of categorizing products and $R \& D$ investment into production processes between different firms.

\subsection{Comparing Approaches}

The simple truth is that tech does not currently have an accepted definition. There are broad theoretical areas of consensus and two standard perspectives for distinguishing between tech and non-tech industries, but they are flawed and inconsistently implemented. The result has been wide variations in measurements of tech's economic footprint developed by government, thinktanks, academics, and the private sector. For example, the Barefoot et al. [1] estimates that the digital economy created 5.9 million jobs in the United States in 2016 while the Deighton et al. [16] estimates that "employment due to the "advertising-supported internet ecosystem" totalled 10.4 million jobs. While these are different terms, a closer look of the language and methods of the two reports reveal very few distinctions between the actual topics.

There are only a handful of research studies that have offered formal definitions for tech, but these vary widely in their definitions. The three prominent industry-level definitions discussed in Section 2.2 [2, 4, 5] combine to identify 73 unique high-tech industries (NAICS codes) within the United States. Yet, the Appendix shows that only 12 of those industries are consistent across those three separate definitions, even when imputing mismatches in the level of industry detail - i.e. when the author matches a three-digit NAICS code to a four-digit NAICS code. And in the literature, it appears only the piece from Kile and Phillips [8] has attempted to help resolve these discrepancies issues through a detailed comparison of previous studies.

The broader set of empirical literature in which researchers have used approximations of tech in order to conduct their analysis offers no further insight. Key studies of these type include: Syverson [17], which examines country-level technology intensity and productivity slowdowns; Fallah and Partidge [11], which examines technology sector employment growth in U.S. counties; and Byrne et al. [18], which examines the impact and relationship of tech and labor productivity. There are numerous other articles, particularly in the productivity literature and innovation literature, that adopt a similar approach. The current paper argues the approaches used by these are effective for their purposes, but blunt and offer no real insight into the theoretical and methodological foundations of a comprehensive tech definition that can be applied across research disciplines. 


\section{Defining Tech}

Rather than simply describing approaches and definitions previously used in the literature, the author hopes to identify a list of core industries comprising tech - a consensus definition with a tangible list of industry codes based on it. This is ambitious; however, the author argues the foundation largely exists and that the necessary missing component - and a key contribution of this paper - is simply pulling together disparate previous approaches.

The author conducts two exercises. First, it compiles a set of expert approaches (those from BLS, Brookings, and CompTIA) and compares them to test the consistency between expert approaches and to identify consensus industries across expert groups. Second, it cross-references these wit R\&D expenditures and STEM employment concentrations in each of the component industries to examine how well they meet quantitative criteria. The paper shows both exercises in the Appendix.

\subsection{General Methodology}

The paper argues that any useful definition of tech will be based on standard industrial classifications. While there are certainly shortcomings to this approach, it is impractical and not particularly helpful to utilize alternative definitional approaches based on proprietary data for firms, processes, etc. The author bases this argument on the reality that governments and numerous think-tanks, non-profits, and private sector firms must rely on standardized industrial classifications.

In its comparison of the approaches in the literature, the paper examines articles which utilized 2012 NAICS codes. This limited the number of definitions to just three: Brookings [5], CompTIA [2], and an update to the BLS definition [4]. The paper identified both exact (where possible) and imputed matches in cases where one of the definitions identified a more refined NAICS code as high-tech, but only a lower digit code was available on the matrix.

The author cross-referenced these industry lists to the 2014 BLS National Employment Matrix to determine the proportion of employees educated in STEM fields using their associated SOC codes (specifically 15-0000, 17-2000, 17-3000, 19-1000, 19-2000, 19-4000, 11-3020, 11-9040, and 11-9120). Following guidance from BLS, the author identified industries that had twice the national proportion of employees educated in STEM as hightech industries. The 2014 national proportion was found to the $2.65 \%$, so the threshold was placed at 5.3\%. Finally, the author collected data on R\&D by industry from the National Science Foundation. 


\subsection{Identifying Consensus?}

There were 37 industries from the BLS definition, 21 from the CompTIA definition, and 50 from the Brookings definition. The paper expected considerable overlap between the industries designated as 'high-tech' among the three approaches reviewed from the literature. Combined, there were 73 unique industries, but only 12 industries appeared in all three lists (about 16\%). Appendix A indicates these in bold text and gray highlight. The paper refers to these as consensus tech industries.

The lack of consistency across all three tech definitions and the internet subsector reinforces the paper's observation on the lack of a standard definition. It also demonstrates that experts disagree widely on what makes up the tech sector and, subsequently, that measurements of it will continue to vary widely even among the leading 'authorities'. The paper argues this simple exercise demonstrates that expert-based definitions of tech should face scrutiny and that robust academic research should not rely on them without some clear justification or methodological supplement. Further, given the weaknesses of any single expert-based definition of tech and the inconsistency between different expert-based definitions, the author argues there are two paths forward.

The first option is to simply use the 12 consensus tech industries identified by the paper or to identify other consensus industries cited by multiple reputable definitions and or that meet accepted characteristics. This provides an easy starting point for future research, but is only a quick fix that fails to completely reconcile the standard definitional approaches documented in the literature.

Table 1 illustrates this first simple option and its issues. It lists the 12 consensus tech industries and compares them with their intensity in R\&D and STEM employment. The paper combines the two metrics into a single tech intensity index by multiplying the R\&D per employee by the Percent STEM employees for each industry using standard deviation units. This effectively produces a weighted measure of both R\&D and STEM, rather than measuring purely volume, and allows the author to compare the tech intensity of the industries according the 1.5 standard deviation criterion proposed by Muro et al. [5]. The table shows that even among the 12 tech consensus industries, three $(25 \%)$ of the industries are below the 1.5-unit cutoff and one is only just at the threshold. 
Defining Tech: An Examination of How the 'Technology' Economy is Measured

Table 1 Comparing Expert Consensus Definitions with Threshold Definitions

\begin{tabular}{llll}
\hline & $\begin{array}{l}\text { Industry } \\
\text { Code }\end{array}$ & $\begin{array}{l}\text { Expert } \\
\text { Consensus } \\
\text { Industry* }\end{array}$ & $\begin{array}{l}\text { Tech } \\
\text { Intensity } \\
\text { Index** }\end{array}$ \\
\hline $\begin{array}{l}\text { Computer and peripheral equipment } \\
\text { manufacturing }\end{array}$ & $3341-$ & $\mathrm{X}$ & 15.3771 \\
\hline $\begin{array}{l}\text { Communications equipment } \\
\text { manufacturing }\end{array}$ & $3342-$ & $\mathrm{X}$ & 6.4004 \\
\hline $\begin{array}{l}\text { Semiconductor and other electronic } \\
\text { component manufacturing }\end{array}$ & $3344-$ & $\mathrm{X}$ & 2.9539 \\
\hline $\begin{array}{l}\text { Navigational, measuring, electromedical, } \\
\text { and control instruments manufacturing }\end{array}$ & $3345-$ & $\mathrm{X}$ & 1.5113 \\
\hline $\begin{array}{l}\text { Manufacturing and reproducing magnetic } \\
\text { and optical media }\end{array}$ & $3346-$ & $\mathrm{X}$ & 3.9437 \\
\hline $\begin{array}{l}\text { Aerospace product and parts } \\
\text { manufacturing }\end{array}$ & $3364-$ & $\mathrm{X}$ & 2.2529 \\
\hline Software publishers & $5112-$ & $\mathrm{X}$ & 8.8623 \\
\hline Satellite telecommunications & $5174-$ & $\mathrm{X}$ & -0.0171 \\
\hline Other telecommunications & $5179-$ & $\mathrm{X}$ & 0.0519 \\
\hline $\begin{array}{l}\text { Data processing, hosting and related } \\
\text { services }\end{array}$ & $518-$ & $\mathrm{X}$ & 1.9965 \\
\hline Other information services & $519-$ & $\mathrm{X}$ & 1.6112 \\
\hline $\begin{array}{l}\text { Computer systems design and related } \\
\text { services }\end{array}$ & $5415-$ & $\mathrm{X}$ & 1.2112 \\
\hline
\end{tabular}

Notes: *Listed as a tech industry in all three of the NAICS-based industry definitions (BLS, Brookings, and CompTIA);

** Index score for \% STEM employment multiplied by R\&D expenditure per employee, shown in SD units

\subsection{A New Conceptualization of Tech}

The second path forward is to move away from a dichotomous (tech vs not tech) mindset entirely and toward a continuous scale of tech. The author argues that previous definitions have relied on definitional approaches that largely traded conceptual accuracy with methodological simplicity. Simply put, there is no dichotomy distinguishing tech firms, products, or industries; rather, there is a continuum of tech intensity among all industries. Further, the author proposes two aspects define this continuum-based approach: 1) technology development and 2) technology application. While imperfect measures, they can currently be captured well by the accepted metrics R\&D development (technology development) and STEM employment (technology application). 
The author measures R\&D per employee and Percent STEM employees for all NAICS industries and converts them into standard deviation units (similar to its technology intensity index, but without the multiplication of the two). The author then plots the codes according to their values for both. Figure 1 provides this plot and marks the 1.5 standard deviation cut-off for both metrics.

The plot in Figure 1 reinforces the authors arguments. The exercise reveals a strikingly clear and conceptually 'clean' separation between tech development (R\&D per employee) and tech application (percent STEM employees). The results show the former metric is far stronger in tech manufacturing and tangible goods production - areas which devote significant time and resources to the development of new, frontier technologies. Conversely, the results show the latter metric is far stronger in less tangible, tech service areas such as research, information processing, data hosting, and others - areas which devote significant time and resources to technology application (the use of existing technologies for the development, discovery, or maintenance of knowledge).

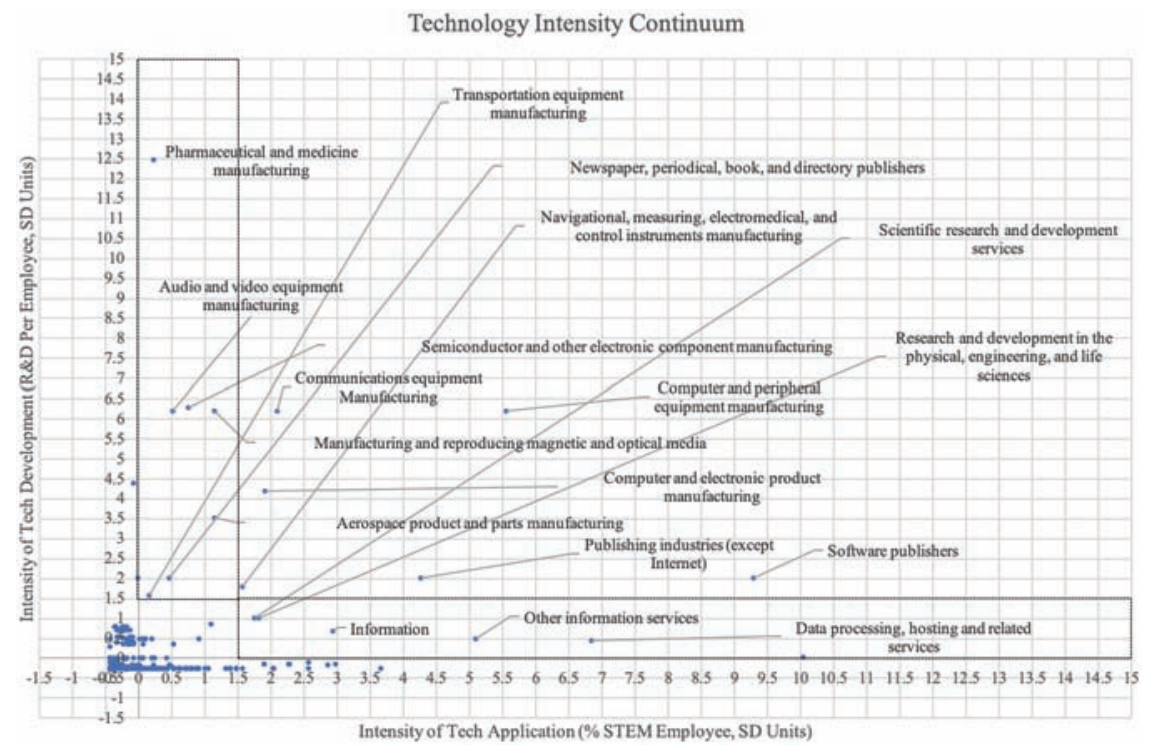

Figure 1 Plotting Technology Sectors Along A Continuum.

Notes: Each blue dot represents a 2- to 6-digit NAICS code. Scale for both axes is standard deviation units (z-scores). 
The figure also shows that even a simple continuum, such as the distinction between tech development and tech application, improves the conceptual 'fit' of the defining threshold metrics - R\&D and STEM employment. The overlapping area - those industries where there is intensity in both technology development and technology application - is quite small, with only a handful (six) of industries within it, including less than intuitive Publishing (not internet). Compare that to the 12 consensus tech industries identified across the 73 industries among all three expert-based definitions and the evidence points to an exaggerated scope among previous approaches - a fact emphasized by the fact that only 4 of the expert-based consensus tech industries appear as high-tech in the paper's proposed continuum-based approach.

\section{Discussion}

The results presented here indicate that only a small number of industries actually comprise tech. At least, there are only 4 to 12 industries that comprise the core of the tech sector according the accepted theoretical conceptualizations and applied approaches defining the sector.

The largest limitation of the current paper is an inability of the author to broaden the conceptualization of tech in theory. The paper utilized established theory and approaches for a systematic review and comparison of definitional

approaches. This adds value by assessing the accuracy and consistency of current approaches while identifying consensus tech industries; however, it fails to address the shortcomings of the theory and conceptualizations themselves.

Current definitions are simply inconsistent and likely do not allow the incorporation of less intuitive industries or firms. For example, current 'expert' approaches likely do not capture tech industries or companies that reside in non-tech areas, such as Airbnb, which likely resides in the Accommodation industry code). Consequently, measurements of the sector vary widely across research.

This observation lends further weight to the paper's two main arguments: 1) that researchers not use expert-based definitions without either a supplementary methodological component and or a clear justification for doing so; and, 2) that researchers use a continuum-based definition of the technology sector, such as the one presented in Figure 1, rather than a binary approach. There are two clear reasons for these arguments, which also correspond to two lessons for future research. 


\section{C. A. Hooton}

First, a continuous scale of tech more accurately captures areas that may be missed by existing approaches. It is too difficult to identify a standalone tech sector comprised of a unique set of industries. Rather, a more accurate conceptualization is that every industry has tech firms within it; thus, better to measure the intensity and use of tech within each industry. The current paper offers a useful approach that repurposes R\&D and STEM metrics to measure both tech development and tech application as well as a single tech intensity metric which combines these two elements. The approaches presented here are a foundation for further work; going forward research should attempt to identify how much tech is in each industry rather than which industries comprise the tech sector.

Second, researchers can utilize or convert a continuous scale approach to estimate the degree to which each industry derives economic activity from tech (e.g. the percent of the Accommodation sector derived from short-term rental platforms). Such a measure, while certainly a large undertaking, would prove immensely valuable, allowing more accurate estimates of technologies' economic contributions and better tracking over time. It could also be modified to capture particular aspects of tech, such as a digital intensity metric (the paper's current index is simple and needs further refinement). Additionally, there is likely a case for the development of one or several alternative indexes; these are all worthwhile endeavors.

\section{Conclusion}

This paper offers the first comprehensive review and critical examination of the theory and empirical approaches for defining the high-technology sector or, simply, tech. Based on existing theory, it identified between 4 to 12 tech industries across approaches that could reasonably be considered as defining the tech sector; however, the paper's analysis demonstrates clear flaws in many of the existing, standard definitions.

The paper concludes from the review and analysis that current definitions are overly broad and include too many industries. Furthermore, the methods and theory underlying them are flawed by their dichotomous perspectives, inconsistencies between their approaches in the application of theory, and their outdated conceptualizations, which miss large portions of the sector because they cannot measure the degree or intensity of tech across all industries. The paper argues that rather than relying on expert-based approaches or dichotomous thresholds, that researchers utilize a conceptualization of tech on continuous scale. 


\section{Appendix}

Table A.1 Tech Sector Definitions from BLS, Brookings, and CompTIA

\begin{tabular}{|c|c|c|c|c|c|}
\hline Industry Title & $\begin{array}{l}\text { Industry } \\
\text { Code }\end{array}$ & $\begin{array}{l}\text { Tech } \\
\text { Intensity } \\
\text { Index }\end{array}$ & BLS & CompTIA & $\begin{array}{l}\text { Brookings } \\
\text { (Muro et al.) }\end{array}$ \\
\hline Oil and gas extraction & $211-$ & -0.15090 & - & - & I \\
\hline Metal ore mining & $2122-$ & -0.16524 & - & - & I \\
\hline $\begin{array}{l}\text { Electric power generation, } \\
\text { transmission and distribution }\end{array}$ & $2211-$ & -0.15568 & - & - & I \\
\hline $\begin{array}{l}\text { Petroleum and coal products } \\
\text { manufacturing }\end{array}$ & $324-$ & -0.06410 & - & - & I \\
\hline Basic chemical manufacturing & $3251-$ & -0.08493 & - & - & $\mathrm{E}$ \\
\hline $\begin{array}{l}\text { Resin, synthetic rubber, and } \\
\text { artificial synthetic fibers and } \\
\text { filaments manufacturing }\end{array}$ & $3252-$ & -0.04032 & - & - & $\mathrm{E}$ \\
\hline $\begin{array}{l}\text { Pesticide, fertilizer, and other } \\
\text { agricultural chemical } \\
\text { manufacturing }\end{array}$ & $3253-$ & -0.12210 & - & - & $\mathrm{E}$ \\
\hline $\begin{array}{l}\text { Pharmaceutical and medicine } \\
\text { manufacturing }\end{array}$ & $3254-$ & 3.17912 & - & - & $\mathrm{E}$ \\
\hline $\begin{array}{l}\text { Other chemical product and } \\
\text { preparation } \\
\text { manufacturing }\end{array}$ & $3259-$ & -0.10723 & - & - & $\mathrm{E}$ \\
\hline $\begin{array}{l}\text { Clay product and refractory } \\
\text { manufacturing }\end{array}$ & $3271-$ & -0.16047 & - & - & $\mathrm{E}$ \\
\hline $\begin{array}{l}\text { Other nonmetallic mineral } \\
\text { product manufacturing }\end{array}$ & $3279-$ & -0.16047 & - & - & $\overline{\mathrm{E}}$ \\
\hline $\begin{array}{l}\text { Iron and steel mills and } \\
\text { ferroalloy manufacturing }\end{array}$ & $3311-$ & -0.16085 & - & - & $\mathrm{E}$ \\
\hline $\begin{array}{l}\text { Alumina and aluminum } \\
\text { production and processing }\end{array}$ & $3313-$ & -0.16345 & - & - & $\mathrm{E}$ \\
\hline Foundries & $3315-$ & -0.16410 & - & - & $\mathrm{E}$ \\
\hline $\begin{array}{l}\text { Agriculture, construction, and } \\
\text { mining machinery manufacturing }\end{array}$ & $3331-$ & -0.08330 & - & - & $\overline{\mathrm{E}}$ \\
\hline $\begin{array}{l}\text { Industrial machinery } \\
\text { manufacturing }\end{array}$ & $3332-$ & -0.02933 & - & I & $\mathrm{E}$ \\
\hline $\begin{array}{l}\text { Commercial and service industry } \\
\text { machinery manufacturing }\end{array}$ & $3333-$ & 0.09334 & $\overline{\mathrm{E}}$ & - & $\mathrm{E}$ \\
\hline $\begin{array}{l}\text { Engine, turbine, and power } \\
\text { transmission equipment } \\
\text { manufacturing }\end{array}$ & $3336-$ & -0.09311 & - & - & $\mathrm{E}$ \\
\hline
\end{tabular}

(Continued) 
Table A.1 Continued

\begin{tabular}{|c|c|c|c|c|c|}
\hline Industry Title & $\begin{array}{l}\text { Industry } \\
\text { Code }\end{array}$ & $\begin{array}{c}\text { Tech } \\
\text { Intensity } \\
\text { Index }\end{array}$ & BLS & CompTIA & $\begin{array}{l}\text { Brookings } \\
\text { (Muro et al.) }\end{array}$ \\
\hline $\begin{array}{l}\text { Other general-purpose } \\
\text { machinery manufacturing }\end{array}$ & $3339-$ & -0.08820 & - & - & $\mathrm{E}$ \\
\hline $\begin{array}{l}\text { Computer and peripheral } \\
\text { equipment manufacturing }\end{array}$ & $3341-$ & 15.37709 & $\mathbf{E}$ & $\mathbf{I}$ & $\mathbf{E}$ \\
\hline $\begin{array}{l}\text { Communications equipment } \\
\text { manufacturing }\end{array}$ & $3342-$ & 6.40043 & $\mathbf{E}$ & $\mathbf{I}$ & $\mathbf{E}$ \\
\hline $\begin{array}{l}\text { Audio and video equipment } \\
\text { manufacturing }\end{array}$ & $3343-$ & 2.29006 & - & I & $\mathrm{E}$ \\
\hline $\begin{array}{l}\text { Semiconductor and other } \\
\text { electronic component } \\
\text { manufacturing }\end{array}$ & $3344-$ & 2.95390 & $\mathbf{E}$ & I & $\mathbf{E}$ \\
\hline $\begin{array}{l}\text { Navigational, measuring, } \\
\text { electromedical, and control } \\
\text { instruments manufacturing }\end{array}$ & $3345-$ & 1.51131 & $\mathbf{E}$ & $\mathbf{I}$ & $\mathbf{E}$ \\
\hline $\begin{array}{l}\text { Manufacturing and } \\
\text { reproducing magnetic and } \\
\text { optical media }\end{array}$ & $3346-$ & 3.94366 & $\mathbf{E}$ & I & $\mathbf{E}$ \\
\hline $\begin{array}{l}\text { Electric lighting equipment } \\
\text { manufacturing }\end{array}$ & $3351-$ & -0.09011 & - & - & $\mathrm{E}$ \\
\hline $\begin{array}{l}\text { Household appliance } \\
\text { manufacturing }\end{array}$ & $3352-$ & -0.13607 & - & - & $\mathrm{E}$ \\
\hline $\begin{array}{l}\text { Electrical equipment } \\
\text { manufacturing }\end{array}$ & $3353-$ & -0.06457 & - & - & $\mathrm{E}$ \\
\hline $\begin{array}{l}\text { Other electrical equipment and } \\
\text { component manufacturing }\end{array}$ & 3359- & -0.06968 & - & - & $E$ \\
\hline $\begin{array}{l}\text { Motor vehicle } \\
\text { manufacturing }\end{array}$ & $3361-$ & -0.12681 & - & - & $\mathrm{E}$ \\
\hline $\begin{array}{l}\text { Motor vehicle body and trailer } \\
\text { manufacturing }\end{array}$ & $3362-$ & -0.13479 & - & - & $\mathrm{E}$ \\
\hline $\begin{array}{l}\text { Motor vehicle parts } \\
\text { manufacturing }\end{array}$ & $3363-$ & -0.07894 & - & - & $\mathrm{E}$ \\
\hline $\begin{array}{l}\text { Aerospace product and parts } \\
\text { manufacturing }\end{array}$ & $3364-$ & 2.25289 & $\mathbf{E}$ & I & $\mathbf{E}$ \\
\hline $\begin{array}{l}\text { Railroad rolling stock } \\
\text { manufacturing }\end{array}$ & $3365-$ & -0.08692 & - & - & $\mathrm{E}$ \\
\hline Ship and boat building & $3366-$ & -0.07894 & - & - & $\mathrm{E}$ \\
\hline $\begin{array}{l}\text { Other transportation equipment } \\
\text { manufacturing }\end{array}$ & $3369-$ & -0.05500 & - & - & $\mathrm{E}$ \\
\hline
\end{tabular}


Table A.1 Continued

\begin{tabular}{|c|c|c|c|c|c|}
\hline Industry Title & $\begin{array}{l}\text { Industry } \\
\text { Code }\end{array}$ & $\begin{array}{l}\text { Tech } \\
\text { Intensity } \\
\text { Index }\end{array}$ & BLS & CompTIA & $\begin{array}{l}\text { Brookings } \\
\text { (Muro et al.) }\end{array}$ \\
\hline $\begin{array}{l}\text { Medical equipment and supplies } \\
\text { manufacturing }\end{array}$ & $3391-$ & -0.05203 & - & - & $\mathrm{E}$ \\
\hline $\begin{array}{l}\text { Other miscellaneous } \\
\text { manufacturing }\end{array}$ & $3399-$ & -0.06410 & - & - & $\mathrm{E}$ \\
\hline $\begin{array}{l}\text { Professional and commercial } \\
\text { equipment and supplies } \\
\text { merchant wholesalers }\end{array}$ & $4234-$ & -0.11707 & $\mathrm{E}$ & I & - \\
\hline $\begin{array}{l}\text { Household appliances and } \\
\text { electrical and electronic goods } \\
\text { merchant wholesalers }\end{array}$ & $4236-$ & -0.14722 & $\mathrm{E}$ & - & - \\
\hline $\begin{array}{l}\text { Electronic shopping and } \\
\text { mail-order houses }\end{array}$ & $4541-$ & -0.14207 & $\mathrm{E}$ & - & - \\
\hline Software publishers & $5112-$ & 8.86226 & $\mathbf{E}$ & $\mathbf{I}$ & $\mathbf{E}$ \\
\hline $\begin{array}{l}\text { Cable and other subscription } \\
\text { programming }\end{array}$ & $5152-$ & 0.26606 & $\mathrm{E}$ & - & $\mathrm{E}$ \\
\hline $\begin{array}{l}\text { Wired telecommunications } \\
\text { carriers }\end{array}$ & $5171-$ & 0.00748 & $\mathrm{E}$ & I & - \\
\hline $\begin{array}{l}\text { Wireless telecommunications } \\
\text { carriers (except satellite) }\end{array}$ & $5172-$ & -0.01707 & $\mathrm{E}$ & - & $\mathrm{E}$ \\
\hline Satellite telecommunications & $5174-$ & $-\mathbf{0 . 0 1 7 0 7}$ & $\mathbf{E}$ & I & $\mathbf{E}$ \\
\hline Other telecommunications & $5179-$ & 0.05190 & $\mathbf{E}$ & $\mathbf{I}$ & $\mathbf{E}$ \\
\hline $\begin{array}{l}\text { Data processing, hosting and } \\
\text { related services }\end{array}$ & $518-$ & 1.99654 & $\mathbf{E}$ & $\mathbf{I}$ & $\mathbf{I}$ \\
\hline Other information services & $519-$ & 1.61116 & $\mathbf{E}$ & I & $\mathbf{I}$ \\
\hline $\begin{array}{l}\text { Monetary authorities-central } \\
\text { bank }\end{array}$ & $521-$ & -0.08398 & $\mathrm{E}$ & - & - \\
\hline $\begin{array}{l}\text { Activities related to } \\
\text { credit intermediation }\end{array}$ & $5223-$ & -0.13656 & $\mathrm{E}$ & - & - \\
\hline $\begin{array}{l}\text { Securities and commodity } \\
\text { contracts intermediation and } \\
\text { brokerage }\end{array}$ & $5231-$ & -0.14023 & $\mathrm{E}$ & - & - \\
\hline $\begin{array}{l}\text { Securities and commodity } \\
\text { exchanges }\end{array}$ & $5232-$ & -0.12994 & $\mathrm{E}$ & - & - \\
\hline $\begin{array}{l}\text { Other financial investment } \\
\text { activities }\end{array}$ & $5239-$ & -0.14354 & $\mathrm{E}$ & - & - \\
\hline $\begin{array}{l}\text { Direct health and medical } \\
\text { insurance carriers }\end{array}$ & 524114 & -0.11670 & $\mathrm{E}$ & - & - \\
\hline $\begin{array}{l}\text { Direct insurance (except life, } \\
\text { health, and medical) carriers }\end{array}$ & $52412-$ & -0.13950 & $\mathrm{E}$ & . & . \\
\hline Other insurance related activities & $52429-$ & -0.14023 & $\mathrm{E}$ & - & - \\
\hline
\end{tabular}


Table A.1 Continued

\begin{tabular}{|c|c|c|c|c|c|}
\hline Industry Title & $\begin{array}{l}\text { Industry } \\
\text { Code }\end{array}$ & $\begin{array}{l}\text { Tech } \\
\text { Intensity } \\
\text { Index }\end{array}$ & BLS & CompTIA & $\begin{array}{l}\text { Brookings } \\
\text { (Muro et al.) }\end{array}$ \\
\hline $\begin{array}{l}\text { Lessors of nonfinancial } \\
\text { intangible assets (except } \\
\text { copyrighted works) }\end{array}$ & $533-$ & -0.14391 & $\mathrm{E}$ & - & - \\
\hline $\begin{array}{l}\text { Architectural, engineering, and } \\
\text { related services }\end{array}$ & $5413-*$ & -0.12029 & - & - & $\mathrm{E}$ \\
\hline Engineering services & $54133-$ & -0.14033 & $\mathrm{E}$ & $\mathrm{E}$ & - \\
\hline Testing laboratories & $54138-$ & -0.15623 & - & $\mathrm{E}$ & - \\
\hline $\begin{array}{l}\text { Computer systems design and } \\
\text { related services }\end{array}$ & $5415-$ & 1.21119 & $\mathbf{E}$ & $\mathbf{I}$ & $\mathbf{E}$ \\
\hline $\begin{array}{l}\text { Management, scientific, and } \\
\text { technical consulting services }\end{array}$ & $5416-$ & -0.12792 & $\mathrm{E}$ & - & $\mathrm{E}$ \\
\hline $\begin{array}{l}\text { Scientific research and } \\
\text { development services }\end{array}$ & 5417-* & 0.98371 & - & I & $\mathrm{E}$ \\
\hline $\begin{array}{l}\text { Research and development in the } \\
\text { physical, engineering, and life } \\
\text { sciences }\end{array}$ & $54171-$ & 1.02206 & $\mathrm{E}$ & - & - \\
\hline $\begin{array}{l}\text { Research and development in the } \\
\text { social sciences and humanities }\end{array}$ & $54172-$ & 0.54427 & $\mathrm{E}$ & - & - \\
\hline $\begin{array}{l}\text { Management of companies and } \\
\text { enterprises }\end{array}$ & $551-$ & -0.12810 & $\mathrm{E}$ & - & - \\
\hline Office administrative services & $5611-$ & -0.14354 & $\mathrm{E}$ & - & - \\
\hline $\begin{array}{l}\text { Business schools and computer } \\
\text { and management training; state, } \\
\text { local, and private }\end{array}$ & $6114-*$ & -0.14685 & $\mathrm{E}$ & I & - \\
\hline $\begin{array}{l}\text { Business schools and computer } \\
\text { and management training; local }\end{array}$ & 611403 & -0.14575 & $\mathrm{E}$ & - & - \\
\hline $\begin{array}{l}\text { Business schools and computer } \\
\text { and management training; } \\
\text { private }\end{array}$ & 611405 & -0.14685 & $\bar{E}$ & - & - \\
\hline $\begin{array}{l}\text { Medical and diagnostic } \\
\text { laboratories }\end{array}$ & $6215-$ & -0.15972 & - & - & $\mathrm{E}$ \\
\hline $\begin{array}{l}\text { Electronic and precision } \\
\text { equipment repair and } \\
\text { maintenance }\end{array}$ & $8112-$ & -0.14501 & $\mathrm{E}$ & I & - \\
\hline
\end{tabular}

Notes: I = Imputed from higher digits; E = Exact match; *Four-digit summary when higher digit levels are also used; Table shows those NAICS industries that were designated as tech sectors in any one of the three NAICS code-based industry definitions (BLS, Brookings, and CompTIA) examined by the paper. Those industries shown in bold and highlighted gray have been defined as tech sectors by all three of the NAICS-based approaches examined in the paper. The tech intensity metric in the third column is an index defined by R\&D expenditure per employee weighted by percent STEM employees in the industry and in standard deviation units (z-score). 


\section{References}

[1] Barefoot, K., Curtis, D., Jolliff, W., Nicholson, J. R., and Omohundro, R. (2018). Defining and Measuring the Digital Economy. US Department of Commerce Bureau of Economic Analysis, Washington, DC, 15.

[2] CompTIA, 'Cyberstates 2016', Research Report, Computing and Technology Industry Association, 2016.

[3] Cortright, J. and Mayer, H. (2001). High tech specialization: a comparison of high technology centers. Washington, DC: Brookings Institution, Center on Urban and Metropolitan Policy.

[4] Heckler, D. E. (2005). High-technology employment: a NAICS-based update. Monthly Lab. Rev., 128, 57.

[5] Muro, M., Rothwell, J., Andes, S., Fikri, K., and Kulkarni, S. (2015). America's advanced industries: what they are, where they are, and why they matter. Brookings.

[6] O'Regan, N., Sims, M. A., and Gallear, D. (2007). Leaders, loungers, laggards: the strategic-planning-environment-performance relationship re-visited in manufacturing SMEs. Journal of Manufacturing Technology Management, 19(1), 6-21.

[7] Steenhuis, H. J., and De Bruijn, E. J. (2006). High technology revisited: definition and position. In Management of Innovation and Technology, 2006 IEEE International Conference on (Vol. 2, pp. 1080-1084). IEEE.

[8] Kile, C. O., and Phillips, M. E. (2009). Using industry classification codes to sample high-technology firms: Analysis and recommendations. Journal of Accounting, Auditing \& Finance, 24(1), 35-58.

[9] Chapple, K., Markusen, A., Schrock, G., Yamamoto, D., and Yu, P. (2004). Gauging metropolitan "high-tech" and "I-tech" activity. Economic Development Quarterly, 18(1), 10-29.

[10] Decker, R. A., Haltiwanger, J., Jarmin, R. S., and Miranda, J. (2016). Declining business dynamism: Implications for productivity. Brookings Institution, Hutchins Center Working Paper.

[11] Fallah, B., Partridge, M. D., and Rickman, D. S. (2013). Geography and high-tech employment growth in US counties. Journal of Economic Geography, 14(4), 683-720.

[12] Haltiwanger, J., Hathaway, I., and Miranda, J. (2014). Declining business dynamism in the US high-technology sector.

[13] Luo, T., and Mann, A. (2011). Survival and growth of Silicon Valley high-tech businesses born in 2000. Monthly Labor Review, 134(9).

[14] Slavtchev, V. and Widerhold, S. 'Does the Technological Content of Government Demand Matter for Private R\&D? Evidence from US States', 
IWH Discussion Papers, No. 10/2014, Halle Institute for Economic Research, 2014.

[15] Hansen, P. A., and Serin, G. (1997). Will low technology products disappear?: The hidden innovation processes in low technology industries. Technological Forecasting and Social Change, 55(2), 179-191.

[16] Deighton, J. (2017). Rethinking the Profession Formerly Known as Advertising: How Data Science Is Disrupting the Work of Agencies. Journal of Advertising Research, 57(4), 357-361.

[17] Syverson, C. (2017). Challenges to mismeasurement explanations for the US productivity slowdown. Journal of Economic Perspectives, 31(2), 165-86.

[18] Byrne, D., Oliner, S. D., and Sichel, D. E. (2017). Prices of hightech products, mismeasurement, and the pace of innovation. Business Economics, 52(2), 103-113.

\section{Biography}

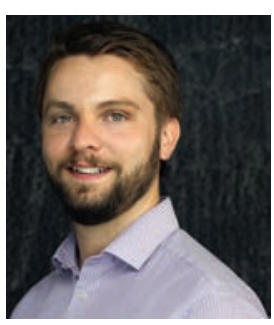

C. A. Hooton is an economist and policy expert specializing in economic development, spatial analysis, and evaluation. He currently serves as the Chief Economist at Internet Association, a leading trade association for internet firms, and as a Senior Scholar at the George Washington University Institute of Public Policy.

Prior to joining Internet Association, Hooton served as a consultant to the World Bank, the Inter-American Development Bank as well as other leading organizations and was formerly a Lecturer at the Social Science Research Methods at the University of Cambridge. He has also written two novels, entitled Observance and Peregrine East, and a travel memoir, entitled How to Backpack With Your Parents. Born and raised in Kansas City, Missouri, Hooton holds degrees from the University of Miami, the London School of Economics, and his doctorate from the University of Cambridge where he also served as the captain of the university's boxing team. 